\title{
A Generational Approach to Somatic Cultures: Modes of Attention to the Young Body in Contemporary Portuguese Society
}

\author{
Vitor Sérgio Ferreira $\mathbb{}$ \\ Instituto de Ciências Sociais, Universidade de Lisboa, 1600-189 Lisbon, Portugal; vitor.ferreira@ics.ulisboa.pt \\ Received: 7 June 2018; Accepted: 6 August 2018; Published: 17 October 2018 \\ check for
updates
}

\begin{abstract}
The aims of this article are to identify, describe, and sociologically understand the different somatic cultures in contemporary Portuguese society-i.e., the distinct ways in which different generations have thought about, used and lived the body from the time of the Estado Novo (the New State, which was the regime that governed Portugal from 1933 to 1974) until the present day. Beginning with the hypothesis that there are different, historically institutionalized, somatic modes of attention to the "young body", the author uses the most relevant institutions of the socialization of the body as analytical dimensions and investigates their main incorporation strategies and models of corporality. This hypothesis is informed by different generational conditions that change people's uses of their body, their experiences of living in it, and their thoughts on the matter. Using these analytical dimensions, the article presents a typology that identifies, describes, and comprehends the three somatic cultures in the recent history of Portuguese society: the culture of physical invigoration that forms part of the legacy of the New State; the culture of physical rejuvenation inherited from youth cultures of the 1960s and 70s, along with the growth of body design industries in the 1980s; and the culture of physical perfection inherited from the biotech culture in the 1990s, accompanied by the radicalization of the body design industry. This approach entails the discussion and reinterpretation of a corpus of historical literature, presenting research data on the body in a defined time period (1930 to date) and space (Portugal), analyzed from an embodied perspective of generational change.
\end{abstract}

Keywords: young body; generation; somatic cultures; Portugal; sociology; social history

\section{Introduction}

Youth is a recently invented and socially constructed category. However, to see it as a mere word [1] or metaphor [2] is an assumption that implies an attitude of extreme nominalism. Although "youth" is a historically and contextually "unstable social fact" [3] and not a biological one, nowadays the body is unquestionably a privileged locus in which to visualize young age in the social arena [4]. This in turn means that being identified as young implies an age codification linked to a certain model of modal corporality [5]-i.e., an established set of bodily traits that are socially recognized and valued as juvenile.

There are norms that frame the social figure of being young and which, to a large extent, are established on the basis of a corporeal criterion. It is important to acknowledge that one of the most visible and privileged attributes that make it possible to identify "youth" as a social category in daily interactions is bodily condition. The young body condition is substantiated by a multiplicity of images and physical performances that are symbolically correlated and assigned to a specific age condition. Ultimately, the demarcation of borders that define being young implies a social reading of attributes associated with the biological process of growth and aging, which are socially codified by relating them to certain phases of the life course. 
The bodily attributes related with the beginning of the youth condition are, for example, the early signs of puberty. These are often experienced with some awkwardness and strangeness by adolescents: pimples on the face, hair appearing in some zones of the body, the beginning of the menstrual cycle for girls, initial ejaculations for boys and so on. The end of the "young age" stage is physically signaled by the initial attributes of "maturity": the first gray hair or baldness, wrinkles, adiposities, a variety of aches and pains, etc. Beyond these phenotypical marks, the public image of being young-based on corporeal appearances (such as clothing and hairstyles) and performances (attitudes, gestures and physical practices) - is also an important reference for the social game of approximation or distance from the youth condition, in relation to the conditions of childhood and adulthood.

Youth is therefore a socially constructed, specific time of life that is codified in the body. The period known as "youth" is becoming increasingly longer [6], and individuals are attempting to extend it due to a social belief nurtured by the commercializing promises of the juvenilization of bodies [7]. In fact, the evolution of the public image of youth has been marked by a progressive attention to bodily image by both younger and less young people alike. This is evident in the exponential increase in advertising seeking to sell objects, practices, and other consumer goods by framing them within contexts of fashion, sport, music, and dance, in which the aesthetic, spectacular, or erotic value of the physical image of youth is intensively explored.

The social value attached to the "young body", and to the body by young people, is not new but has a recent social history in Portugal. In the 1980s, a number of empirical studies on the Portuguese reality highlighted the image of the body as one of the most important aspects of both the public image of youth [8] and the social life of young people [9]. The "physical aspect" was particularly relevant when people defined and distinguished themselves and their peer groups, and entailed not just physical attributes themselves, but also "the look". On the other hand, some older research also pointed to the existence of a generalized and consensual agreement on the assumption that the latest generations are distinguished from their predecessors by the fact that they attach greater value to the body, clothes and physical activities [10,11].

The body thus emerges as part of the hardcore of referents which serve as poles in the structuring of the symbolic borders that define current young people as a social condition and simultaneously distinguish them as a social generation $[12,13]^{1}$ (p. 87). What clothes they wear, the shoes they put on, what they use to garnish, to disguise, what they try to modify or to keep, are resources which make their body a signifier reality, which ensure "the passage from the sensitive to the sense" [14] (p. 286), acquiring meanings that express important social differentiations. At the end of the day, these bodily signs are referential dimensions that acquire a wide social visibility and unanimity as identity signs of "youth" today, extrapolating criteria rooted in mere age proximity and acquiring a generational configuration.

However, this contemporary trend towards attaching value to the "young body" and to the body by young people has not been closely accompanied by youth studies. To a large extent this may be because the work of sociological deconstruction and social archaeology with regard to the categories "youth" or "young" has employed strategies of avoidance and distancing from biologisms, naturalisms and evolutionisms ingrained in the category "adolescence". This was indeed an analytical category which was widely celebrated and legitimated by psychology, but which always looked at "adolescents" from the perspective of biological and physiological development, thereby assuming that this phase of life coincides with "puberty".

In this context, sociology has not shown much interest in the corporeal dimension that is itself implied in this "new age of life" [15], either in terms of the symbolic value and social use which the figure of the "young body" has assumed in contemporary society, or the symbolic value and social use

1 Contrasting with the notion of demographic generation defined merely by age criteria, some literature on the topic argues that a social generation is established by means of a self-reference to other generations (from which it sees itself as distinct). 
which young people assign to their own body in their representations of and social experiences with it. It was only more recently, over the course of the 1990s, that sociology started to look more carefully at young people from the point of view of their bodies, but even then, the extent to which the topic was of interest to the youth studies agenda was still much more marginal than the value that is socially assigned to it among the new younger generations.

A context like this invites youth studies to pay more attention to social representations of the "young body", to the relationships young people establish with their own bodies, and to the interactions and sociabilities they build on the basis of bodily practices, be they imagetic, kinetic or sensitive [16]. It has proved analytically productive for me to cross the areas of the sociology of youth and the sociology of the body. Recently rescued by sociology from the life sciences [17], this live and developing structure that is the organic body is also a lived body, in the first person and among other people [18]. Although usually understood as an individual and natural subject, the human body is experienced in distinct ways, not only because of each body's specific physical properties, but also considering the different social and cultural contexts in which it is born, grows, is modified (voluntarily and involuntarily) and dies. As Boltanski pointed out in the 1970s, the experience of the body is conditioned "first, by the reception system between the set of corporeal behaviors of the members of the same group, and secondly, by the relations system that joins those corporeal behaviors and the objective conditions of existence proper to that group" [19] (p. 208).

This is the perspective from which I return to an old concept of Boltanski's: somatic culture, as a system of specific rules, attitudes, and codes of body production, perception, and consumption applied to a particular social formation, or to the different objective conditions that underpin the systems of social differentiation and inequality which characterize each social formation (class, age, generation, gender, ethnicity, etc.), with repercussions for the distinct ways in which the body is lived socially [20] (pp. 135-173). In recovering this concept, I consider its heuristic relevance as a descriptive and comprehensive operator of a set of associations and disjunctions relating to the ways in which the body is used, approached, thought and classified by different (institutional and informal) social actors, in certain cultural forms situated in time and space (geographic and social). The concept of somatic culture is thus useful to an understanding of the different ways in which the body is socially lived and experienced in time and space, given that it corresponds to the socio-symbolic structure which frames certain somatic modes of attention-i.e., "culturally elaborated ways of attending to and with one's body in surroundings that include the embodied presence of others" [18] (p. 138).

In this sense, the concept of somatic culture allows the current context of body hysteria [21] to be seen from a historical perspective-marked by the social proliferation of experiential or institutional discourses, images, activities and worries about the carnal dimension of life-and to go beyond an understanding that is founded on a supposed historical absence of the body in daily life. In fact, as suggested by Neves, the presence of the body has always been "amazingly obsessive in the history of the western world" [22] (p. 66). The fact is that a set of social processes has recently transformed earlier versions of the symbolic structure of contemporary somatic culture, modifying the conditions of body socialization (incorporation), of body reflexivity (thought body), and of body experience (lived body) of the new generation in relation to previous ones.

How did this come about? As Crespo says, if in the past the body was assimilated to an "actual object, existing by itself, in its biological materiality", nowadays "the body is not immutable data, rather revealing itself in its historicity, being the origin and the outcome of a long process of social elaboration" [23] (p. 8). The gradual emancipation of the body towards its apparent natural condition implies a set of structural sociocultural, political, economic and technological transformations that interact with an intense rationalization, commodification, individuation and privatization of the body in recent social history.

Against this background, the aim of this paper is to analyze the social conditions that gave rise to the process of the denaturalization of the body in Portuguese social history, namely from the Estado Novo (the New State, which was the regime that governed Portugal from 1933 to 1974) until the present 
day. This period was chosen because it enables us to identify, describe and sociologically comprehend the different somatic cultures that still coexist in contemporary Portuguese society, revealing distinct ways of using, thinking and living the body in time which, to a large extent, possess a generational configuration. Considering the theoretical structure presented above, the selected dimensions of analysis for each somatic culture are the most relevant institutions of body socialization, together with their ways of thinking/conceiving the body and the strategies of incorporation they have applied in order to obtain the models of corporality they value and seek to disseminate socially.

Given the high social and symbolic value attached to it across time and space by the institutions of body socialization, the figure of the "young body" and of the bodies of young people forms a privileged locus in this essay. Despite the different ways of attending to the "young body" in time and space-i.e., the different somatic modes of attention towards the "young body" — the fact is that historically, young people's bodies have always occupied a central position in the reflexivity and practices of different institutions of body socialization across time and space.

Within the scope of these theoretical issues, I introduce a typology identifying three somatic cultures that are still present in contemporary Portuguese society: (1) a culture of physical invigoration, which is a legacy of the New State; (2) a culture of physical rejuvenation, inherited from the youth cultures of the 1960s and 70s and the expansion of the body design industries in the 1980s; (3) a culture of physical perfection, heir to the biotechnological culture of the 1990s and of the latest radicalization of the body design industry. I take a corpus of historical literature and research that was developed in Portugal and provides a broad description of the somatic modes of attention to the body during the New State, in the period following the revolution that overthrew the regime on 25 April 1974, and today, and reframe the data from the theoretical perspective of somatic cultures. My goal in doing so is to sociologically understand each of the three somatic cultures as potential socio-symbolic structures for different generational ways of living the body. As Csordas put it, "an approach to cultural phenomena through embodiment should also make possible the reinterpretation of data already analyzed from other standpoints" [18] (p. 146).

Over the course of the historical narrative, I recover some empirical data from research projects I participated in or coordinated, in more of an illustrative than a demonstrative way with regard to the set of hypotheses I am developing for further, more in-depth and more theoretically focused research. I use some specific elements from a set of institutional and media sources published during and after the New State (1970s and 1980s), with discursive and visual data collected as part of the editorial projects entitled in English A History of Private Life in Portugal: These Days [24] and A History of Sport in Portugal [25], in order to illustrate and describe the somatic cultures of physical invigoration and physical rejuvenation. These are complemented by a few extracts from a large set of comprehensive interviews [26] with young people engaging in different bodily regimes, such as tattooing and body-piercing [27], ${ }^{2}$ diets and bodybuilding, ${ }^{3}$ which serve to help understand the contemporary somatic culture of physical perfection.

2 Fifteen comprehensive individual interviews with extensively tattooed young people were collected as part of the research project "Corporeidades In-Disciplinadas: vivências e sentidos juvenis" [In-disciplined corporalities: youth experiences and meanings], which I undertook in 2002-2006 for my PhD. All the methodological procedures and ethical protocols developed and employed in the research were approved by the Sociology evaluation panel which the Portuguese Foundation for Science and Technology (FCT) designated for the 2001 Call for PhD Scholarships (REF. SFRH/BD/5264/2001).

3 Fifteen comprehensive individual interviews with young women who said they were anorexic or were having anorexic episodes during their life courses, plus 15 comprehensive individual interviews with young men who said they were addicted to bodybuilding, were collected as part of the research project "Corporeidades Hiper-Disciplinadas: vivencias e sentidos juvenis" [Hyper-disciplined corporalities: youth experiences and meanings], which I undertook in 2007-2012 for my post-doc. All the methodological procedures and ethical protocols developed and employed in the research were approved by the Sociology evaluation panel which the Portuguese Foundation for Science and Technology (FCT) designated for the 2006 Call for Post-Doctoral Fellowships (REF. SFRH/BBD/27158/2006). 


\section{Somatic Culture of Physical Invigoration}

From its establishment onwards, the Estado Novo (New State)—an authoritarian regime inspired by fascism and the social doctrine of the Catholic Church-paid close attention to the image, movements, emotions and physical energy of its citizens, and tried to socialize, regulate and discipline the ways in which the Portuguese people looked, acted, and expressed desires, feelings and corporeal abilities. The New State's leader, António de Oliveira Salazar, gave the body a prominent place in his political project. As part of the latter, it was considered that maintaining the individual body helped maintain the social body, and that even in the most intimate privacy of home and bed and in the most basic care, aesthetics and behaviors, bodies should obey and reiterate the collective order, reflecting and extending the regime's moral and political values. This was a physical ideal of virtue and modesty, obedience and discipline, sobriety and austerity, hygiene and robustness; a body dedicated to God, Nation, Family, and Work [28].

In order to adjust people's bodies to the prescribed corporeal model-puritan and austere in look, humble and ceremonious in attitude, robust and vigorous in movement-the New State equipped itself with a set of institutions and mechanisms of control, monitoring and socialization of the body. Their purpose was to soften the body's look, movements and emotions, while simultaneously enhancing its strength and energy $[29,30]$. The primary target was the body of the youngest. Aware that they might provide access to mundane spaces of circulation of ideas and ideals which could potentially be dangerous for the regime, the New State chose not to leave the exclusive responsibility for socializing youngsters in the hands of the school, the family or the Church, instead creating its own organizations for the "comprehensive education of youth".

Considering different statutes and physical missions for young male and female bodies, the New State created the Organização Nacional Mocidade Portuguesa (MP) [National Organization of Portuguese Youth] for young men in 1936, and the Mocidade Portuguesa Feminina (MPF) [Female Portuguese Youth] for young women in the following year. These two youth organizations established a clear gap between both the social indoctrination of young men on the one hand and young women on the other, and the strategies for training their bodies. This gap was visible from the outset in the imposition of moral limits on the display of the female body, with a set of increasingly severe prohibitions on how it should be exhibited in public. In this domain, the restrictions on the physical education, clothes and bathing suits of girls in the Mocidade Portuguesa Feminina were exemplary by the standards of Christian morals [31] (pp. 348-349). The length of skirts generated heated debates in the specialized press of the day-opponents of the trend towards shorter skirts invoked questions of morals and elegance, while defenders presented arguments based on cost, hygiene and pragmatism [32] (p. 316).

The policy of controlling the female body not only addressed the issue of modest clothing, but also sought to regulate exaggerated forms of behavior. Behavior was supposed to be characterized by correct and elegant movements, and by restraint in the public expression of certain gestures and facial expressions, such as laughing or speaking loudly, chatting or displaying grimaces of impatience or suspicion. Single young women were required to maintain self-control, politeness and good sense in spaces of social coexistence: "A true girl does not use complicated hairstyles, gaudy garments, exaggerated necklines. She does not adopt studied postures like the 'stars'. She does not make herself interesting with squeals and chuckles just for show. A true girl is distinguished by naturalness and correction. It is simplicity that determines the elegance of fashion and manners" [33].

The strategy was thus to make the female body as invisible as possible in the public space. Any sign, expression or adornment that might attract glances should be avoided or hidden-a concern that was also present in many of the etiquette manuals of the time. The body of the "virtuous woman" should be seen as a "temple of the soul", sacred, preserved in the "gifts" and "natural" attributes that God gave her. The young woman's body was socialized primarily with a view to reproduction, playing her role as the "mother of the family", and thus "remaining in the domestic space" and "not using makeup, laughing or being educated, but being discreet, intelligent, disciplined, polished in manners and poise" [34] (p. 134). 
The political investment in the physical socialization of male bodies was directed towards the glorification of the Nation. The strength and tonus of the male body and the order and collective discipline displayed during the public marches of the youth affiliated to the Mocidade Portuguesa symbolically served to project the strength of the State. In its daily life, the expression of the male body was expected to convey the image of the "head of the family", classical and sober, mature and anonymous, kempt and smelling good, with well-groomed hair and wearing impeccable suits and starched collars. Men were not supposed to be attached to fashion and manners-an area that ought to be left to their wives. Indeed, the recommendations on the care that men should take were principally published in women's magazines, clearly indicating that a woman's role was thought to include the responsibility for her husband's appearance.

In short, in both men and women value was attached to a quiet, contained and discreet corporality at the level of the gesture and imagetic expression, all in accordance with the rules of "good taste" and "good manners". Any gesture that emphasized a person's public presence, such as wearing useless adornments or clothes that underlined or revealed certain parts of the body, could suggest excess and become a target for criticism. Attempts were thus made to more efficiently indoctrinate the youth from the urban and more highly schooled elites, who were not always docile, obedient and acritical. With a view to the socialization of the bodies of working-class children, above all those who were in the poorest economic circumstances and were therefore more distant from the instances of body control, in 1935 the regime also created the Fundação Nacional para a Alegria no Trabalho (FNAT) [National Foundation for Joy in Work], in order to provide them with physical activities involving contact with the sun, the sea and the countryside.

Because physical ills were symbolically represented as symptoms of moral-and when disseminated, national—weakness, a number of institutional strategies were developed in order to transform potentially meager, skinny and bony bodies into robust, ruddy and upright ones, capable of facing any adversities for the good of the Nation: parades, outdoor activities, camping, summer camps, bathing in the sea, and above all else, physical education. The Ling system, also known as "Swedish gymnastics", was institutionally adopted to this end [35-38]. It was a rational system of localized and sequentially measured movements, promoting breathing, verticalization, uprightness and correction of the body. Performed in synchronized collectives and white uniforms, these movements suggested an image of discipline and order, physical and moral pureness, cooperation and national exhortation, that both blurred and established the uniqueness of each physical body on behalf of the social body.

The regime's body rectification goals were thus not achievable by means of an athletic physical culture, with narcissistic intentions of personal satisfaction, but by a moralizing physical education, designed to fulfill Juvenal's expression mens sana in corpore sano, a "saying that righteous Salazarism interpreted to mean the formation of the mind in and through discipline and submission of the body" [30] (p. 109). The main driving force in the national plan to physically invigorate the people was thus the moral regeneration of youth in general and the most privileged urban youth in particular, with the latter considered to be adepts of a certain relaxation of customs or a resistance associated with a bohemian life.

The culture of invigoration promoted by the regime also sought to address the economy of the body. Along with objectives of a moral nature, the body socialization strategies pursued by official institutions were designed to prevent the population from wasting energy on parties, amusement, or acts of violence. Augmenting physical education was also intended to promote the "greater efficiency" of the "useful work" done by workers' bodies in such a way as to "reduce [the amount of public] funds [spent on] public health" [39].

Similarly, the body was colonized by several scientific disciplines and submitted to rationalized health and hygiene norms. It would seem that the political action targeted at the body in these areas no longer included an eminently religious content, instead taking on economic outlines and demanding more rationalized behaviors based on scientific knowledge about managing illness. Medical, pedagogical and police authorities cooperated to monitor and control people's bodies, as well 
as in the scientific validation of the strategies that were adopted, in a joint action undertaken in the fields of human motricity, public health and social prophylaxis.

Faced with social realities of the day, which included extreme physiological, nutritional and civilizational shortages, the authorities sought to promote public health and foster improvements in the nutrition, health and hygiene of the poorest sections of the Portuguese population. This ill-nourished majority, with debilitated, careworn, dirty and tired bodies, represented around three quarters of the rural population in 1950: "wage-earning rural workers, shepherds, blacksmiths, millers, innkeepers were the foremost characters in a universe dominated by unthinkable misery" [40] (p. 220).

The goals of promoting "devotion to water and soap" and punishing "everyone who excreted outdoors" were proclaimed by the Direção Geral da Saúde [Directorate-General of Health] in 1950 [41]. The sanitary education campaigns initiated by the Liga Portuguesa de Profilaxia Social (LPPS) [Portuguese League of Social Prophylaxis] were intensified, with the aim of disseminating civilizational principles of coexistence and gradually increasing the hygiene of public spaces, which had thus far been difficult to incorporate into the mentality of the Portuguese people. The many campaigns conducted by the LPPS included a "campaign against bare feet"—one of the longest-running (1927-1965)—and another "against the habit of hawking and spitting outdoors"; the latter was such a legitimate practice, according to existing social codes, that "it was not rare to see people of high social status, even ladies, engaging in this serious disrespect to the code of good manners, infringing it in a reprehensible way" [42].

In this rationalization process, the body was institutionally thought and designed as a production tool. By acquiring knowledge about and monitoring and disciplining bodily habits regarding hygiene, eating and physical activity, the regime tried to promote the body's efficiency and performance in its role as the primary tool of the country's workforce. In a society where the production system was heavily based on the human and animal workforce, physical capital was the only resource that guaranteed the subsistence of a population whose material needs were not provided for in other ways [43] (p. 34). Even for the countless peasants who began to migrate to the city or to foreign countries over the course of the 1950s, the body, and its strength, energy and vitality, continued to be their only saleable capital, as laborers in the developing major industries or domestic servants in bourgeois homes.

The value of work and physical effort formed the basis for a certain social discourse on the part of the New State, which disapproved of the indolence of the "idle classes", pleasure-lovers and an easy life. However, these particular members of society didn't have to worry about subsistence; they were more concerned with "the look". The "high society" body ended up mirroring the regime's ideology. Many of its corporeal doctrines were adopted in order to make social distances visible. Even though the New State's official discourse frowned on sophisticated forms of body modification other than those that promoted the "naturalness" and "spontaneity" of a vertical, healthy, clean and courteous body, "actually, what this game of the spontaneous fails to hide is all the incessant work of the 'social body' on the 'real body', a canonical conformation to the severities of fashion, an urge to transform the biological destiny of the body into a symbolic instrument of status, of value" [44] (pp. 349-350).

With access to a set of material and social resources unavailable to other layers of the population, the bodies of the bourgeois elites were civilized by imitating distinctive foreign models: either those adopted by wealthy refugees who escaped the Great War by moving to Lisbon and who circulated in exclusive and selective sociabilities; or international and especially French models of fashion, which were institutionalized as paradigms of "good taste", "elegance" and "sobriety", hand-made from toiles ${ }^{4}$ by private dressmakers and major maisons de couture.

4 Name given to special sewing molds that French dressmakers and seamstresses sold to their Portuguese counterparts and were originally acquired from the great Parisian maisons de couture. 
However, the profusion of communication media caused the ideals and expectations of "being in fashion" to expand to an increasingly wider range of social classes. The popularization of the cinema, and then the emergence of television in 1957 [45], played a role in this process, disseminating new ways of living and producing the body. For "modern" young women, "being in fashion" changed from copying the ladylike models of their mothers to imitating the seductive forms and walks of Hollywood divas, as seen on cinema screens and in magazines that explored the glamour of the bodies and the lives of emergent cinematographic myths. Marcel Mauss ethnographically noted a similar process in the case of young women in New York and Paris: "A kind of revelation came to me in hospital. I was ill in New York. I wondered where previously I had seen girls walking as my nurses walked. I had the time to think about it. At last I realized that it was at the cinema. Returning to France, I noticed how common this gait was, especially in Paris; the girls were French and they too were walking in this way. In fact, American walking fashions had begun to arrive over here, thanks to the cinema." [46] (p. 100).

\section{Somatic Culture of Physical Rejuvenation}

A certain degree of daring and a desire to break with existing attitudes and practices in relation to the body took hold among a larger number of urban young people in the 1960s. They produced their bodies not with reference to the regime's official socializing institutions, but in the light of the more mundane corporalities they saw every day in magazines, at the cinema and on TV.

The "modern woman" gradually affirmed herself in the public domain-at schools and universities, in industry and offices, in mundane spaces like cafés or night clubs. Previously modest in their movements, concealed in their look and oppressed in their emotions, many women then began to display a body that was increasingly vainer, lively, dancing, and sensual. In terms of their experiences, pleasure and self-determination were made possible by the advent of the contraceptive pill in 1958. In their looks, there was a casualness and freedom provided by the emergence of prêt-à-porter.

The female body rarely had the opportunity to be contemplated naked, even in private. In the 1960s, however, the "modern woman's" body undressed itself in terms of both clothes and prejudices, unveiling itself to other people's eyes at the beach, in the evening and in daily life. The miniskirt was a thunderous success, with the female press emphasizing the "new meaning" of its colors and shapes, which were considered "spectacular" and "amusing to the eyes and the spirit" [47]. In addition to hemlines rising above the knee, necklines became pronounced, rigid lines were abandoned in favor of a light, joyful, and comfortable silhouette, and the use of pants spread, highlighting feminine shapes.

Although officially forbidden, the bikini started to be popular on Portuguese beaches at the end of the 1960s. In 1966, the magazine Modas $\mathcal{E}$ Bordados included an advert for the most recent novelty in Portugal with regard to female hygiene-tampons—which allowed women to feel "free at the beach all summer long". This ad reveals that something was changing in Portugal in attitudes to the exhibition of the female body in public spaces: "The body is uncovered, reveals and exhibits itself, gaining a new functional effectiveness. [ . . . ] Fatness is not prettiness anymore, it becomes a tenebrous concern for those who need to exhibit an elegant body exempt from superfluous masses, not only in bathing suits, but also in evening toilettes" [44] (p. 350).

Men also started to change their body image, with a wider range of clothing on offer and a greater democratization of men's garments. The traditional industry of individual tailor's workshops went into crisis with the emergence of prêt-à-porter, a reality that also won over the male consumer [32]. Men began to assimilate fashionable trends in hairstyles, beards and mustaches, which became longer and more spontaneous. The hairspray and pomade that were previously used to shape hair gave way to the unkemptness of a "young fashion" that affirmed itself nationally and internationally.

"Nowadays, fashion is a youth phenomenon" was a headline in 1967 [48] (p. 26). The 1960s were in fact a time of the rejuvenation of bodies, with the adoption by younger generations of a more informal and colorful visual image. Prêt-à-porter was increasingly common in Portuguese streets and magazines, (un)covering a young body which, in the city, had acquired a degree of consumerism and autonomy. A body trying to be free from official models and conventions, namely gender conventions. 
The unisex fashion began to emerge, despite accusations and lamentations that it was no longer possible to distinguish between males and females: both shopped in the same stores and went to the same hairdressers, and wore their hair long or short, with bell-bottom jeans, leather jackets, and a variety of adornments.

Individual difference and social rebellion were values that the bodies of the youngest sought to express, inspired by a number of youth "subcultures" that were recognized in other European countries and the USA by their spectacular garments: rockabillies, teddy boys, hippies, rockers and other youth subcultures of the time ... The body also became free in dance, with effusive movements that escaped the need for a partner and searched for ways to excite the senses. Ié-ié-an adaptation of the English phoneme yeah and representative of the Beatlemania experienced in Portugal—vibrantly inflamed the bodies that filled the stage and seats of Lisbon's Monumental Theater, either in competitions between new values present in modern music, or at the concerts of international stars.

The dominant production references for the body image of young people were no longer the sophistication of movie stars, but the cheerful irreverence of emerging national and international rock and pop stars. Radio and TV opened up horizons that included other sound and imagetic realities, other products and values, disseminating signs of and for a new generation, with bodies, senses and mentalities that were distinct from those of the past. The multiple musical styles disseminated by these media brought with them styles of dress, dance and behavior that inspired many urban youngsters from the middle and higher layers of Portuguese society.

These transformations expanded in the 1970s, and tended to become generalized after the revolution in April 1974. This was a time when Portuguese society transversally lived through a period of revolutionary exaltation, celebrating the social freedom it had won. In the bodies with their raised fists, adornments and libertarian clothes that included unbuttoned shirts with pointed collars and unseemly pants instead of ladylike skirts, the country experienced a collective euphoria to which it was unused: "The country is in a shambles and Lisbon is the mirror of this chaos that precedes new times, with the heart of the Rossio infested with hippies and punks and radical political refugees [... ]. Very young people, dressed in a whole rainbow of colors, from the darkest to the brightest. Young men and women in tunics and Afghan coats, ripped, threadbare, mended jeans-extremely expensive and imported!--long skirts, miniskirts or hotpants" [49] (p. 141).

Although not everything was allowed, much was demanded. Information was diversified and many of the subjects that had previously been taboo-examples include sex, abortion, and homosexuality - were addressed and discussed in the media, at schools and in political life as rights to something that was seen as personal property and began to be claimed as private: the body. In the 1980s, regardless of social class or sex, Portuguese young people distinguished themselves from previous generations by attaching greater importance to the body, physical activities and sex life, as well as by their very different tastes in clothing [10] (pp. 198-210) [8] (p. 1062).

To the context of sexual freedom inherited from the 1970s was added the individual desire to become attractive and different, just like the worldly bodies with which the Portuguese came into contact every day through the media and advertising. "Originality" and "style" were values that crossed the body productions which demarcated the new "youth tribes" that emerged in Portugal's public urban spaces. The creative phantasy that characterized fashion and manners in the mid-1980s came to transform the body in terms of the way that it was dressed, the shoes it wore, the way it was combed or decorated, into a personalization resource that was invaluable to younger generations [50] (p. 341).

Fashion began to give way to style, in which the value of individual difference, more than of social distinction, was bodily explored. The absolutism of haute couture was dethroned by the expansion of the increasingly inventive prêt-à-porter industry, which assimilated a variety of international trends and became accessible to a larger number of people. The seasonal dictatorship of a single line including a complete look with all the details of beauty, hairstyle and accessories was de-multiplied, and body production norms were assumed to be more indicative than directive [51] (p. 158) [52] (p. 59). 
As the fashion industry expanded, there also arose a body design industry offering a plethora of body-maintenance products, techniques and services. New national and international stores, companies and services established themselves in the Portuguese market, promising an adjustment to the aesthetic rules of the moment and simultaneously producing the massified illusion that each person was able to plan and sculpt their own body within a globally established beauty standard.

Amidst the booming body design industry, there arose a range of commercial initiatives linked to physical activity, either at the level of investment in products for use in the domestic space-from exercise systems, specialized magazines, clothes, and footwear to a variety of home equipment-or at the level of investment in collective spaces [25]. In the 1980s, the latter started to take the shape of "neighborhood" gyms, where people could access modern ergonomic equipment with which to exercise their body individually or collectively, trying new and appealing physical activities imported from the USA, like aerobics, along with other modalities that were created and imported under the conceptual umbrella of body training systems or group fitness programs. ${ }^{5}$

In the 1990s, "neighborhood gyms" were then threatened by health clubs-multi-functional spaces that were depositaries of diverse valences in the fields of aesthetics, health, nurturing and body leisure, many of them representative of international chains that set up in some of the major Portuguese cities. The process of the growth and commercial diversification of indoor physical activities benefited from a favorable economic conjuncture, characterized by the increased purchasing power of the Portuguese population and the improvement in the life conditions of some of its sectors and social groups, namely from its middle classes. The proliferation of gyms and health clubs was also favored by the increase in both average life expectancy and the process of schooling-dynamics that made retired people and young students two essential target groups for such spaces.

The paradigm of a "healthy mind in a healthy body" was replaced by other, more imagetic ones, illustrated by the sayings "look good, feel good" or "be somebody". "Being in shape" implies exhibiting (certain) shapes, certain forms. The most highly valued manifestation of the "healthy body" was no longer its efficiency, strength and resistance, but its look. Health acquired a cosmetic aspect and became an aesthetic phenomenon: it was not enough to remain healthy, good health had to be made evident, namely by preserving a rejuvenated body image: "While the vocation of 'physical education' gyms was to discipline the body to educate better, healthier and more competent citizens, preparing them for the challenges of the new societies that emerged with industrialization, the current health clubs associate youth, beauty and body health with self-confidence, self-esteem and well-being, offering products and services aimed to 'shape the body' to the extent of the cultural needs and concerns of each individual" [53] (p. 54).

The whole panoply of products, services and techniques made available by the expanding body design industry emphasized mercantile promises of bodily rejuvenation, nurturing the mythology of a perpetual "young body" that is also attractive, healthy and energetic. Promoted to the status of a value of reference and reverence, this corporality corresponds to a body image materialized in the desire to obtain the smoothest, firmest skin and a silhouette that matches the imaginary biology of youth; to preserve an active and always fit body far from the threat of illness or the forewarning of death; to build a seductive and sensual body, always desirable and eager; to explore a hedonistic and desiring body that provides immediate delight and pleasure.

In its beauty, curves, health, vitality and sensuality, the "young body" appeared as ideal(ized) reality, glorified archetype, fetishized, envied, persistently desired, nurturing the anxieties and expectations of many, young and less young. The bodily attitudes and practices cultivated by young people were reflected in the corporeal experience of their parents' generation, who were pressured to maintain the youthfulness of their bodies and to be open to the value of the "young body". A "bigger inversion in behavioral models took place", says Lipovetsky, justifying this claim with a quote from

5 Such as body pump, body balance, body combat, body step, body attack, body jam, body jump or spinning-RPM. 
Yves Saint-Laurent: “once, a girl wanted to look like her mother. Currently, we see the opposite”. From the same perspective, Lipovetsky adds that "the cult of youth and the cult of the body walk side by side" [54] (p. 166).

It can thus be claimed that, to a great extent, the culture of physical rejuvenation emerges from the commodification process which the social production of the body begins to demand. Capitalism continues the work of colonizing the human body as a resource to be capitalized, albeit now in a gradual emancipation from the distress of manual work and the physical constraints of the duty to be laborious. It surrenders to the vacations and free time that pertain to a consumer society, to sport, sun, sex and sea [55] (p. 58), to the cult of pleasure, well-being, good shape, a young, attractive, athletic, healthy, energetic body that desires (and is desired) and shows no calluses or signs of work. In this context, the body becomes socially invested and valued not as a productive body, but as a produced body, "the most beautiful, precious and radiating" of all consumer objects [56] (p. 212). While it loses its functional value as a tool that produces a workforce, its symbolic value grows as an accessory of the self's presence in the world [57] (p. 42), the cultural sign most closely associated with the person and the expression of their personal identity, socially denoting and distinguishing each individual as a singular and unique subject [58].

The body is thus glimpsed in emancipation from its supposed "natural condition". Within the context of the several available possibilities in terms of corporeal production and modification, the body becomes socially conceived and lived, not as an inherited and untouchable destiny, but as a projected and modifiable resource, subject to acts of will that express its owner's expectations and identity desires, within both the diverse possibilities currently offered by body design industries and the inequality of the actual ability to access them. As Giddens pointed out, if in the past the body was thought as being the locus of the soul, and later as the center of obscure and perverse needs, the body now becomes more available "to be worked", and the whole of its exterior, or at least the visible part, becomes permeable to the "offers" emanating from society [59] (p. 201).

\section{Somatic Culture of Physical Perfection}

In complicity with media channels that are becoming more specialized in the body, an increasingly more diverse and sophisticated body design industry is creating the social illusion of the individual's omnipotence in relation to the body, not only in terms of its exterior look but also its internal functioning. However, these days this illusion goes far beyond the yearnings for and expectations of conserving a perpetual present. More than just the rejuvenation of the body, people dream of its perfection. The image of a "young body" is now surpassed by the ideals of a "perfect body" as a corporality to be reverenced and serve as a reference.

The goods, services and technologies recently made available by the body design industry no longer act at just the most superficial and holistic level of the body in order to ensure its maintenance (in the way the physical activity systems available in the 1980s did), but instead introduce the hypothesis of body's correction using techniques and products that are increasingly focused, detailed and invasive of its inner boundaries. Corporeal production and modification no longer operate solely on the whole body and in a standardized way, but increasingly in relation its tiniest parts [60-62] and focused on particular and concrete details of a singular body. In this context, the contemporary body is increasingly thought and lived as a reality that is amenable to being constructed, manufactured- "a kit, an addition of occasionally detachable parts at the disposal of the individual" [57] (p. 24), each driving specialized forms of consumption that seek to match the ideals of each body's perfectibility.

The exponential growth of today's body design industry extends far beyond the "empire of vanities" of fashions and cosmetics, with medicine, nutrition and motricity sciences, technology and genetic engineering, among other fields, associated in the production of a range of techniques and technologies that increasingly invade the body in its daily life. The resources that the current body design industry develops and places on the market comprise more diverse scopes, with more diversified, creative and personalized products. 
Along with the cosmetic products that act on the skin's surface, the good-looking segment is developing a whole set of dietary, chemical and biological resources that intervene in the body's biological processes and internal mechanisms to modify corporeal shapes and silhouettes (specific diets, nutritional supplements, diuretics, steroid-anabolic drugs, etc.). Jewelry and makeup, which ephemerally decorate the skin, are now joined by things that invade it permanently, such as tattoos and multiple types of body-piercing and other accessories. In academies and health clubs, collective exercise systems with standardized choreographies are articulated with services that provide customized responses to the ambitions, problems, risks and physiological and morphologic characteristics of each body, accompanied by the proliferation of the figure of the personal trainer. ${ }^{6}$ Plastic surgery has become a popular way to "correct" or value specific parts of the body, going far beyond the renewal or stretching of the epidermis to disguise signs of age. ${ }^{7}$ The developments in the fields of genetics and biotechnology have opened up the possibility of directly acting on the cellular formula of the subject's tissues and/or organs.

The development of the good-looking industry segment has been accompanied by that of the corporeal well-doing segment, formed by goods, services and technologies that fulfil the high standards of performance, health and vitality demanded of the human body in contemporary society, which always wants it to be dynamic and active: energy drinks and products that make it possible to handle an increasingly accelerated lifestyle; chemicals that are ingested in order to sleep or wake up, or provide long periods of activity, increasing the capacity for effort and overcoming fatigue or the desire for sleep; products that improve the memory or ensure improved sexual performance and efficiency, true "potions of elongation and prolongation" .. These are just some of the pharmacological or "natural" prostheses for correcting and regulating each body that are available nowadays, considering the needs for a performance that enables users to face the challenges of the contemporary world.

Finally, we have also witnessed the development of an area devoted to corporeal well-being, comprising products, services and technologies that go far beyond a hygiene-based concern about being kempt, promising pleasure and personal satisfaction by means of the body: a whole range of accessories that offer relaxation and a pleasant stimulation of the senses (candles, soaps, essential oils and perfumed bubble-bath foams); various therapies at the service of the body or anchored in it to serve the psyche (such as spas, bioenergetic therapies and meditation, as well as the innumerable types of massages and other activities imported from the eastern hemisphere); and the pharmacological prostheses that regulate, dominate and/or transform the mood-i.e., the emotional tonality of the individual's relationship with the world, either in a context of pathological malaise (like antidepressants and anxiolytic drugs), or in ludic contexts (like many psychotropic substances currently consumed by some youth) [57] (pp. 53-58).

Along with the development of the body design industry, and to a great extent supporting and promoting it, Portuguese society has also seen the emergence of an increasing thematic and media diffusion of images of and information about the body, not only through advertising, but also in other, journalistic, formats: "magazines, programs and thematic TV channels, newspapers, advertising and public medical debates disseminate more or less specialized information on nutrition and physical exercise, presenting solutions that promise physical and psychological health or body transformation" [30] (p. 152).

Challenging the boundary between fiction and reality, the mediatic messages transmitted in these specialized forms tend to disseminate the belief that, by following the instructions of a certain product

6 A physical activity professional who is asked to draw up a suitable training program for a particular body and to individually follow up the program's implementation; a symbol of egobuilding par excellence [63] (p. 129).

7 See, for instance, Rodrigues's paper [64] on vaginal plastic surgery, where the desire to improve certain physiological functions is outweighed by the will to morphologically aestheticize the organ-a motivational reconfiguration that is transversal to the plastic surgery which many other organs of the human body are currently undergoing. 
or service to the letter, it is possible to attain the desired ideal of body perfectibility. At the same time, they make individuals more aware of and reflective on their external look, comforting them with icons that attach a certain definition to (and actually shape) ideals of physical perfection-"dream bodies" that leave the kingdom of the exception and invade daily life.

By widely exploring body images that establish high standards of attractiveness and corporeal performance, the action of the media and the market enhances feelings of dissatisfaction with and physical incompetence in the image that each person develops of their own body: in Portugal, at the turn of the millennium, more than a third of young people between the ages of 15 and 29 revealed a desire to improve their shape and physical aspect, with around $20 \%$ of the youth universe saying that they regularly (often or occasionally) feel that they do not like their body as it is [50] (pp. 275-280).

These are effects that materialize in (among other behaviors) the intensification of strategies for monitoring the shapes and functions of the body, often along with an "at risk" form of bodily management, when adherence to certain body modification practices, such as diets or physical activity, occurs to a radical extent [65]. It is in this context that the occurrence of some behaviors known to be psychopathological disorders-anorexia or binge-eating disorder, for example-has increased in Portuguese society, namely among the youngest.

V., a young woman (aged 28 years), told me about the anorexia she experienced between the ages of 15 and 22:

It all had a little bit to do with the ideal of perfection. Because everything was linked to that — being the best student, having a perfect body—it all had to do with that standard. So I was the best student, I was praised because I wrote well, and yet something was missing, and that was being pretty, being perfect. Like the models I used to see on TV and all those things; like some friends of mine who didn't make any effort at all and were like what I would have wanted to be. ${ }^{8}$

B., a young man (aged 28 years) who was a bodybuilder, explained the following to me about his well-built body, which he had cultivated since he was 19:

I began to take supplements, a little protein, a little creatinine. However, I was told about anabolic steroids, and I tried them ... [ ... ] Spectacular, really! The person even reaches a level... really good, indeed! The quality is enormous! That's why they say that the guys who start to do these things, later it becomes an addiction. [ ... ] I became addicted to that. I even became addicted to the gym... If I didn't go, it was like a disease for me ... I had to go and train ... I was really obsessed with that ... [ . . . I had a goal, I wanted to be big. And I became big! [ ... ] The ideal (body) was ... yes, the goal was to attain a body like that of those guys we see around the place, in those magazines, I don't know, all well-built ... [ . . . ] Like Schwarzenegger, for instance, who was Mister Universe ... ${ }^{8}$

This is the context in which the uses of many of the body modification techniques that are currently available on the market, or their corporeal results, are socially perceived, above all among the older generations, as "abuses" of the body, "excessive", "exaggerated", "extremes", "unnecessary", body "mutilations" or "disfigurements" made in furtherance of supposedly shallow and futile aesthetic motivations. However, when they decorate their skin with tattoos or piercings, take anabolics or follow radical diets to modify their silhouette (just a few examples of the techniques I researched $[24,66]$ ), and even when they run risks, young subjects believe that in doing so they are exercising a basic right: to the fruition of an individual legacy which they perceive as their private property and over which they believe they possess complete authority.

M., a young man (aged 25 years) whose body was covered by tattoos, heatedly said:

8 Individual interview conducted within the scope of the research project "Corporeidades Hiper-Disciplinadas: vivencias e sentidos juvenis" [Hyper-disciplined corporalities: youth experiences and meanings]. 
No one is going to tell me what I do or don't do with my body! It's mine, first and foremost! It's not my mother's, it's not my father's, who are responsible for me being alive. Even they are not the ones who can control what I do or don't do. Only I, no one else, can say what I do with my body! ${ }^{9}$

A., a young (aged 24 years) female medical student had, since her adolescence, developed an eating restriction she believed to be anorexia, although it had never been diagnosed and clinically followed-up. She described the following: ${ }^{8}$

I always thought I was controlling everything [in the weight-loss process] [ ... ]. I thought I had to control that way of being and that [my] weight. [ ... ] I thought they wanted to control me, but that nobody would control me, because I controlled myself. [ ... ] I thought they wouldn't control me anymore, because I was the one who knew what I wanted, and I was moving forward with it. [ ... ] And we think we're controlling [it], but we aren't.

In the frenzy to conform to a "perfect body", these young people voluntarily subject their body to almost sacrificial sports or alimentary restriction regimes under the illusion that this will allow them to dominate biological mechanisms; and based on a feeling of control over their own body, these young subjects build up a subjective feeling of empowerment in relation to both their body and their identity. This is a fiction that not infrequently compromises biological sustainability itself and endangers the organism's homeostatic balance. Modifying the body thus configures a person's ownership of themselves, celebrating in the eyes of others the power to (self-) determine and (self-) control their own actions-a power which these young subjects know is fragile and vulnerable in the face of the conditionings imposed on them in contemporary society. The testimonies show how many young people in fact find in the body a performative place for the expression and implementation of a way of thinking freedom and individual autonomy, when facing forms of social control to which they are subjected in their daily life.

The meanings invested in the uses of body-perfecting strategies are not merely of an aesthetic order, but also emancipatory. They are uses and abuses of the body that often come to challenge the instances which, in several domains of social life (family, school, professional, medical, legal, etc.), are traditionally authorized to exert the power to produce and regulate the corporeal figure and gestures. The body thus appears to be capitalized as an individual legacy in the subject's struggle for their place in the world, for the control of themselves and their life.

In passing, it is worth noting that this is one of the major traits that mark contemporary somatic culture, demarcating the current civilization of the body's newness in relation to the past. To a great extent, it results in a structural process which I call a social privatization of the body, and which occurred in Portuguese society over the course of the second half of the 20th century [24], as it did within the context of many other contemporary western societies. This means that, in terms of the reflexivity and experience of the body, while we observe both its gradual exposition and denudation in the public space and an apparent liberalization of its use and even abuse, the body has been socially understood as a private and individual "good", an item of property in relation to which each person understands they have the complete right and individual authority to intervene and make choices.

This process has not been not uncontroversial. There has been a set of social struggles to claim the power of self-determination and personal control over the body itself, namely vis-a-vis the state. While some of these struggles are limited to the informality of individual manifestations and reactions within the boundaries of each person's life world, others have taken on wider and more organized forms of citizenship, developed within the scope of associations and social movements (such as feminist or LGBTQ+ movements) and even finding a place on political party agendas.

9 Individual interview conducted within the scope of the research project "Corporeidades In-Disciplinadas: vivências e sentidos juvenis" [In-disciplined corporalities: youth experiences and meanings]. 
These causes have been diverse-examples include the "right" to contraception and abortion, to pleasure and a free sexuality, to the rental or sale of corporeal organs, tissues and fluids, to the free modification of any part of the body, from a mere piercing, to tattooing, to the surgical alteration of organs. The most extreme is perhaps terminating the body's life, with appeals for the legal recognition of formats such as the "living will" or "euthanasia", when the individual's physical and/or mental conditions do not allow them to exercise their will for and in relation to themselves.

On the other hand, I also consider that the process of body privatization is not solely substantiated by the struggles to claim rights to the free use and expression of and individual authority over the body. It also lies in collective dynamics of individual accountability for the body itself, which are the organizer of a new psychic economy that tends to intimately regulate emotions, manners and "the look". While in the first place, each person has the full right to their body, they are equally responsible for the fulfilment of a set of social duties linked to this "good". Duties that mean not only taking care of the body's look, vitality and mood, but also being attentive to the length and quality of its life, playing a preponderant role in the control and timely identification of the symptoms of diverse pathologies (cancer, cardiovascular conditions, etc.), in the prevention of risky behaviors (namely by reducing alcohol and tobacco consumption, doing physical exercise and only engaging in protected sex), and the avoidance of excesses (food, exposure to the sun, medicalization, etc.).

Thus, while at first sight the body privatization process seems to correspond to a gradual disappearance of normative interdicts, in fact we find that it is an expression of a new social distribution of constraints and body disciplines, which are subtler than in the past because they are voluntary, de-multiplied and discreet. The successive forms of corporeal release that have taken place translate not an eclipse of the exterior constraints on the body, but their displacement to an individual level, operating by means of increasingly imperceptible, seductive and efficient mechanisms of internalization and reproduction of new body norms and standards.

\section{Conclusions}

Notwithstanding its discreetness, the struggle for the control of the body's meanings, behaviors and pleasures has been a crucial one in the last few decades, with the body as the place where the social is more firmly represented as individual and the policies are better disguised as nature. This was the political project that underlay the somatic culture of physical invigoration promoted by the Estado Novo (New State): to build a body disguised in a "naturalness" that would mirror its deeper values and act in conformity with and the interest of the regime. A body thought and lived as a tool to be taken care of as a workforce, socially valued for the labor income it provides and as an instrument of the moral expression of a collective, socialized in the dependence of a nationalistic collective project and monitored according to very strict and conservative ethical-moral standards.

The socialization spaces (the country's schools, as well as the Organização Nacional Mocidade Portuguesa and the Mocidade Portuguesa Feminina, allied with religious education institutions) directly created and controlled by the powers that be, cultivated the body as a territory of interdictions, sacred, untouchable, only amenable to rectification to the extent of that which was understood to be its "naturalness": a discreet, kempt and healthy body, ready to serve the state by working, reproducing, and obeying the morals of the day. As such, the political regime called on the knowledge and action of medical, physical education and religious professionals to help convince the Portuguese people that their bodies should become accustomed to new conservative fashions and new civilizational manners. These recruited agents undertook the task of correcting and monitoring in accordance with a set of social and political values, with strategies that were differentiated in such a way as to suit quite distinct target groups: simple people from the countryside, unruly and idle bohemians from the cities, youth threatened by various kinds of temptation.

However, from the mid-20th century onwards, various social forces-not only political (such as the feminist movement), but also mundane (like the market and the media)—started to subject the body to a process of denaturalization, emancipating it from an attitude that saw it as a genetically 
inherited destiny in relation to which the only key concern was to preserve its vitality. Under the social, cultural and economic conditions inherited by post-revolutionary Portugal (i.e., after 1974), the body, in the way that it is kept, rejuvenated or improved, was turned into an important accessory of the individual's presence and social recognition in the world, to be planned according to their desire, persistence and resources. A private legacy that each person must explore, manage and capitalize as best as possible, considering the new aesthetic and ethical imperatives established by the markets of good-looking, well-doing, and well-being.

Whereas, under the aegis of the somatic culture of physical invigoration, the control of excesses in gestures, silhouettes and emotions was clearly undertaken by means of the action of institutions like the police, medicine, religion, and school, which were charged with enforcing and monitoring the multiple institutionalized corporeal interdicts, the somatic culture of body perfection makes the individual themselves accountable for that same regulation and control, with constant attention to its presentation, forms, performance and disposition. Individuals are invited to responsibly disguise signs of aging, eradicate symptoms of physical degradation, improve or maintain shape, correct defects, and improve performances and moods. Perpetually subjected to their own view of themselves, constant self-monitoring and self-disciplinary strategies are "naturally" assumed, incorporated and transformed into automatisms and obligations to be fulfilled within the scope of one's private life, often under the epithet of "a healthy lifestyle". The body that is publicly presented as personal and free thus finds itself to be one that is privately socialized and disciplined after all.

Funding: This research was funded by the Portuguese Foundation for Science and Technology (FCT), as part of the research projects: "Corporeidades In-Disciplinadas: vivências e sentidos juvenis" [In-disciplined corporalities: youth experiences and meanings], undertaken in 2002-2006 with a PhD grant (SFRH/BD/5264/2001); and "Corporeidades Hiper-Disciplinadas: vivências e sentidos juvenis" [Hyper-disciplined corporalities: youth experiences and meanings], undertaken in 2007-2012 with a post-doc fellowship (SFRH/BBD/27158/2006). The English translation and revision of this article were carried out with the support provided by FCT to the Strategic Program of ICS-ULisboa (UID/SOC/50013/2013).

Acknowledgments: I thank the anonymous reviewers for their feedback on the final text and their valuable insights and critiques.

Conflicts of Interest: The author declares no conflict of interest.

\section{References}

1. Bourdieu, P. La jeunesse n'est qu'un mot. In Questions de Sociologie; Bourdieu, P., Ed.; Minuit: Paris, France, 1980; pp. 143-154.

2. Feixa, C. La Joventut com a Metàfora; Secretaria General de Joventut: Barcelona, Spain, 1993.

3. Gauthier, M. L'âge des jeunes: 'un fait social instable'. Lien Soc. Polit. 2000, 43, 23-32. [CrossRef]

4. Bytheway, B.; Johnson, J. The sight of age. In The Body in Everyday Life; Nettleton, S., Watson, J., Eds.; Routledge: London, UK, 1998; pp. 243-257.

5. Berthelot, J.-M. Le corps contemporain, figures et structures de la corporéité. Rech. Sociol. 1998, 29, 7-18.

6. Ferreira, V.S.; Nunes, C. Les trajectories de passage à l'âge adulte en Europe. Polit. Soc. Fam. 2010, 102, 21-38. [CrossRef]

7. Featherstone, M.; Wernick, A. Images of Aging: Cultural Representations of Later Life; Routledge: London, UK, 1995.

8. Schmidt, L. A evolução da imagem pública da juventude portuguesa: 1974-1984. Anál. Soc. 1985, 21, 1053-1966.

9. Schmidt, L. Publicidade versus consumo: Os jovens preferem as 'colas'. In Estruturas Sociais e Desenvolvimento, Actas do II Congresso Português de Sociologia; Fragmentos: Lisboa, Portugal, 1993; Volume 2, pp. 271-281.

10. Conde, I. A identidade Social e Nacional dos Jovens; Instituto da Juventude: Lisboa, Portugal, 1989.

11. Ferreira, V.S. Atitudes perante a sociedade. In Gerações e Valores na Sociedade Portuguesa Contemporânea; Pais, J.M., Ed.; Secretaria de Estado da Juventude: Lisboa, Portugal, 1998; pp. 149-244.

12. Mannheim, K. Le Problème des Générations; Nathan: Paris, France, 1990.

13. Nunes, A.S. Questões Preliminares sobre as Ciências Sociais; Presença: Lisboa, Portugal, 1987. 
14. Barthes, R. Sistema da Moda; Edições 70: Lisboa, Portugal, 1999.

15. Galland, O. Un nouvel âge de la vie. Rev. Fr. Sociol. 1990, 31, 529-551. [CrossRef]

16. Ferreira, V.S. Youth scenes, body marks and bio-sociabilities. Young 2009, 18, 285-306. [CrossRef]

17. Ferreira, V.S. Resgates sociológicos do corpo: Esboço de um percurso conceptual. Anál. Soc. 2013, 208, 494-528.

18. Csordas, T.J. Somatic modes of attention. Cult. Anthropol. 1993, 8, 135-156. [CrossRef]

19. Boltanski, L. Les usages sociaux du corps. Annales 1975, 26, 205-233. [CrossRef]

20. Boltanski, L. As Classes Sociais e o Corpo; Paz e Terra: São Paulo, Brazil, 2004.

21. Cruz, M.T. A histeria do corpo. Rev. Comun. Ling. 2000, 28, 363-375.

22. Neves, H. Ausência presença do corpo na cultura ocidental: O corpo (des)apropriado. Manifesto 2004, 5, 66-78.

23. Crespo, J. A História do Corpo; Difel: Lisboa, Portugal, 1990.

24. Ferreira, V.S. Modas e modos: A privatização do corpo no espaço público português. In História da vida Privada em Portugal: Os Nossos Dias; Nunes de Almeida, A., Ed.; Círculo dos Leitores: Lisboa, Portugal, 2011; pp. 242-276.

25. Ferreira, V.S. Pesos, halteres e sentidos dos corpos (h)alterados: Um século de musculação em Portugal. In Uma História do Desporto em Portugal; Neves, J., Domingos, N., Eds.; Quidnovi: Vila do Conde, Portugal, 2011; Volume 3, pp. 231-257.

26. Ferreira, V.S. Arts and tricks of comprehensive interview. Saúd. Soc. 2014, 23, 118-130.

27. Ferreira, V.S. Becoming a heavily tattooed young body: From a bodily experience to a body project. Youth Soc. 2014, 46, 303-337. [CrossRef]

28. Reis, A. Os valores salazaristas. In Portugal Contemporâneo (1926-1958); Reis, A., Ed.; Alfa: Lisboa, Portugal, 1990; Volume 4, pp. 333-338.

29. Drumond, M. Ao bem do desporto e da nação: Relações entre esporte e política no Estado Novo português (1933-1945). Rev. Estud. Políticos 2013, 7, 298-318.

30. Gomes, R. Poder e saber sobre o corpo: A educação física no Estado Novo (1936-1945). Bol. Soc. Port. Educ. Fís. 1991, 2-3, 109-136.

31. Pimentel, I.F. História das Organizações Femininas no Estado Novo; Círculo de Leitores: Lisboa, Portugal, 2001.

32. Cardim, V.C. Fashion, Design, Cultura e Identidade: A Costura Social da Moda em Portugal no Século XX; Tese de Doutoramento em Antropologia Cultural e Social, Universidade Nova de Lisboa, Faculdade de Ciências Sociais e Humanas: Lisboa, Portugal, 1998.

33. Anonymous. Magazine Menina e Moça; Mocidade Portuguesa Feminina: Lisboa, Portugal, 1949; p. 24

34. Brasão, I. Dons e Disciplinas do Corpo Feminino: Os Discursos Sobre o Corpo na História do Estado Novo; Comissão para a Igualdade e para os Direitos das Mulheres: Lisboa, Portugal, 1999.

35. Carvalho, L.M. Explorando as transferências educacionais nas primeiras décadas do século XX. Anál. Soc. 2005, 40, 499-518.

36. Castanheira de Oliveira, J. A educação Física na Escola Primária do Estado Novo; Edições Tenacitas: Coimbra, Portugal, 2002.

37. Crespo, J. História da educação física em Portugal: Os antecedentes da criação do INEF. Ludens 1977, 2, $45-52$.

38. Hasse, M. O outro corpo. Ingrid de Figueiredo (Fröken) e o desenvolvimento da educação física em Portugal (1938-1981). Ex Aequo 2001, 4, 41-56.

39. Pereira, C.M. Problemas da Mocidade Portuguesa; Tipografia Angrense: Angra do Heroísmo, Portugal, 1941.

40. Mónica, M.F. A evolução dos costumes em Portugal, 1960-1995. In Situação Social em Portugal: 1960-1995; Barreto, A., Ed.; Imprensa de Ciências Sociais: Lisboa, Portugal, 1996; pp. 215-231.

41. Direção Geral da Saúde. Cartilha de Sanidade Para a Conduta do Povo Português; Publicação dos Serviços de Saúde e Assistência Social: Lisboa, Portugal, 1950.

42. Liga Portuguesa de Profilaxia Social. Escarrar, Cuspir: Um Hábito Perigoso e Nojento; Edições LPPS: Porto, Portugal, 1944.

43. Raposo, P. Corpos, Arados e Romarias; Escher: Lisboa, Portugal, 1991.

44. Pais, J.M. Austeridade e moralismo dos padrões estéticos. In Portugal Contemporâneo (1926-1958); Reis, A., Ed.; Alfa: Lisboa, Portugal, 1990; Volume 6, pp. 349-352. 
45. Reis, A. A televisão: Arma do poder e janela para o mundo. In Portugal Contemporâneo (1958-1974); Reis, A., Ed.; Alfa: Lisboa, Portugal, 1990; Volume 5, pp. 203-206.

46. Mauss, M. Body techniques. In Sociology and Psychology: Essays; Mauss, M., Ed.; Routledge and Kegan Paul: London, UK, 1979; pp. 97-123.

47. Anonymous. As linhas com que se cose Mary Quant. Mag. Sem. Fem. 1967, 51, $22-23$.

48. Sampaio, S. A moda de hoje é um fenómeno de juventude. Mag. Sem. Fem. 1967, 51, $26-27$.

49. Gonzaga, M. António Variações: Entre Braga e Nova Iorque; Ancora Editora: Porto, Portugal, 2006.

50. Ferreira, V.S. Atitudes dos jovens portugueses perante o corpo. In Condutas de Risco, Práticas Culturais e Atitudes Perante o Corpo; Pais, J.M., Cabral, M.V., Eds.; Celta: Oeiras, Portugal, 2003; pp. 265-366.

51. Gomes, R. Novos corpos para novas personagens: Ensaio sobre a 'manutenção da forma' e o cuidado de si. Bol. Soc. Port. Educ. Fís. 2005, 30, 151-162.

52. Lipovetsky, G. A Era do Vazio: Ensaio Sobre o Individualismo Contemporâneo; Relógio D'Água: Lisboa, Portugal, 1989.

53. Fortuna, C.; Ferreira, D.; Domingues, M. Cultura, Corpo e Comércio: Tendências Socioculturais Relacionadas com a Estética e o Bem-Estar; Observatório do Comércio: Lisboa, Portugal, 2002.

54. Lipovetsky, G. O Império do Efémero; Dom Quixote: Lisboa, Portugal, 1989.

55. Sant'anna, D.B. Corpos de Passagem: Ensaios Sobre a Subjetividade Contemporânea; Estação Liberdade: São Paulo, Brazil, 2001.

56. Baudrillard, J. A Sociedade de Consumo; Edições 70: Lisboa, Portugal, 1975.

57. Le Breton, D. L'adieu au Corps; Métailié: Paris, France, 1999.

58. Ferreira, V.S. Be some body: Modificação corporal e plasticidade identitária na sociedade contemporânea. In Itinerários. A Investigação Nos 25 Anos do ICS; Cabral, M.V., Wall, K., Aboim, S., Carreira da Silva, F., Eds.; Imprensa de Ciências Sociais: Lisboa, Portugal, 2008; pp. 671-689.

59. Giddens, A. Modernidade e Identidade Pessoal; Celta: Oeiras, Portugal, 1997.

60. Seale, C.; Cavers, D.; Dixon-Woods, M. Commodification of body parts: By medicine or by media? Body Soc. 2006, 12, 25-42. [CrossRef]

61. Sharp, L.A. The commodification of the body and its parts. Annu. Rev. Anthropol. 2000, 29, $287-328$. [CrossRef] [PubMed]

62. Sheper-Hugues, N. Bodies for sale-Whole or in parts. In Commodifying Bodies; Sheper-Hugues, N., Wacquant, L., Eds.; Sage: London, UK, 2001; pp. 1-8.

63. Lipovetsky, G. O Crepúsculo do Dever: A Ética Indolor dos Novos Tempos Democráticos; Dom Quixote: Lisboa, Portugal, 1994.

64. Rodrigues, S. From vaginal exception to exceptional vagina: The biopolitics of female genital cosmetic surgery. Sexualities 2012, 15, 778-794. [CrossRef]

65. Ferreira, V.S. O 'jovem radical' contemporâneo: Novos sentidos de um qualificativo juvenil. Crít. Soc. Rev. Cult. Política 2011, 1, 107-127.

66. Ferreira, V.S. Marcas que Demarcam: Tatuagem, Body Piercing e Culturas Juvenis; Imprensa de Ciências Sociais: Lisboa, Portugal, 2008.

(C) 2018 by the author. Licensee MDPI, Basel, Switzerland. This article is an open access article distributed under the terms and conditions of the Creative Commons Attribution (CC BY) license (http:/ / creativecommons.org/licenses/by/4.0/). 